\title{
Angola, a Nation in Pieces in José Eduardo Agualusa's Estação das chuvas
}

RAQUEL RIBEIRO

University of Edinburgh

\begin{abstract}
In this article, I examine José Eduardo Agualusa's Estação das chuvas (1996), as a novel that lays bare the contradictions of the MPLA's revolutionary process after Angola's independence. I begin with a discussion of the proximity between trauma and (the impossibility) of fiction. I then consider the challenges Angolan writers face in presenting an alternative discourse to the "one-party, one-people, one-nation" narrative propagated by the MPLA). Finally, I discuss how Estação das chuvas, which complicates both truth/verisimilitud and history/fiction, presents an alternative vision of Angola's national narrative.
\end{abstract}

Keywords: Angolan literature; MPLA; UNITA; Truth and fiction; Nation

The Angolan civil war broke out in 1975 and lasted 27 years. Yet there are still very few literary accounts of the conflict by Angolan writers. Novels about the civil war have been scarce, and there are few first person or testimonial records by those who participated directly in the conflict, as victims or perpetrators. The war was an enduring presence in Angolan literature in the 1980s, 1990s, and 2000s, but always as something distant. Generally, books do not explicitly evoke the conflict, international military interventions (South African, Soviet, Cuban), its conscripts, prisoners, and atrocities perpetrated by both the MPLA and UNITA. Texts that dealt with it at the time left its contradictions and ideological complexities aside, focusing instead on how it forced millions to migrate to 
Luanda, its consequences for families, and the hardships of daily life for certain classes of Angolans.

There are, however, some exceptions: José Eduardo Agualusa's Estação das chuvas (1996) is one of them, published after the 1992 elections that brought the civil war to a temporary halt. ${ }^{1}$ UNITA did not accept the MPLA's electoral victory and the war resumed for another ten years. In this article, I will examine Estação das chuvas as a civil war novel that lays bare the contradictions of the MPLA's revolutionary process after Angola's independence. I start with a discussion of the proximity between trauma and (the impossibility) of fiction. I then consider the challenges Angolan writers face in presenting an alternative discourse to the "one-party, one-people, one-nation" narrative propagated by the MPLA, making Angola a notable example of what Achille Mbembe terms a "postcolonial potentate" (42). Finally, I discuss how Estação das chuvas, which complicates truth and verisimilitude, and history and fiction, presents an alternative vision of Angola's national narrative.

\section{Wounds, trauma and Angolan literature}

In 1996, at the height of the second phase of the civil war, Patrick Chabal pointed out in his seminal book on the postcolonial literatures of Lusophone Africa that Angolans (and Mozambicans, too) still lacked the necessary distance to be able to write about their own civil wars (24). During the 1980s, Angolan writers and intellectuals seemed concerned about re-writing the colonial period from a postand anti-colonial perspective. The "empire" was finally "writing back" to its colonizer. The 1970s and 1980s were also the decades in which many works written under colonialism, and not previously published, came to light. They focused on the liberation war rather than on the fratricidal war that followed.

Agualusa has long written about memory, trauma and forgetting in Angolan society. In a personal testimony given at a colloquium in 2012, he talks about his experience of growing up in Angola as a witness of conflict: "Eu cresci com a guerra como um pano de fundo.... As minhas memórias de infância são sempre

\footnotetext{
${ }^{1}$ Sousa Jamba's Patriots (1990) is the other exception, the only Angolan novel that presents the "other side" of the war and addresses the legitimacy of UNITA's fight in the south of the country.
} 
também memórias de guerra, de violências" ("A literatura" 101). $\mathrm{He}$ acknowledges that Angola's long wars are still "dentro das pessoas," and goes on to say that, despite their end, "ainda há fragmentos dessa guerra visíveis; [m]ais do que tudo, são as pessoas que não percebem que tem essa destruição dentro de si" (“A literatura" 102).

In what could be seen as a response to Patrick Chabal, Agualusa explained that Angola and Mozambique dealt with the wounds of their civil wars in different ways. The Mozambican writer, Mia Couto, for instance, "tem defendido o esquecimento. Inclusive, faz isso nos livros dele. Essencialmente, o que ele diz é que o trauma é tão pesado, tão profundo que a estratégia das pessoas é esquecer" ("A literatura" 103). Agualusa, in contrast, does not believe in the virtues of forgetting, and he argues strongly for literature's role in helping people to come to terms with the past. The writer's role is, for Agualusa, fundamental in a country where "a esmagadora maioria das pessoas não tem a possibilidade de fazer ouvir a sua voz" ("A literatura" 103). Literature functions as "um lugar, um espaço, um território de debate, um território de pensamento, um território de ideias" ("A literatura" 103).

Agualusa laments the lack of Angolan writers prepared to discuss the war and its consequences, something he seeks to address in his own work. He is one of the exceptions, proving the rule that, in Angola, the writer as a dynamic force providing the possibility of confrontation and reconciliation with the past is still a dormant figure. Concomitantly, Angolan society is yet to come to terms with painful issues of collective memory inscribed as cultural knowledge. As Erll and Rigney posit, "by imaginatively representing acts of recollection, literature makes remembrance observable. As such it not only helps produce collective memory ... but also cultural knowledge about how memory works for individuals and groups. Seen in this light, literature might be called a 'mimesis' of memory" (113). When a wound is not addressed, it cannot heal and its associated trauma persists. As Cathy Caruth argues, trauma is "always the story of a wound that cries out, that addresses us in an attempt to tell us of a reality or truth that is not otherwise available. This truth, in its delayed appearance and its belated address, cannot be linked only to what is known, but also to what remains unknown in our very actions and our language" (4, my emphasis). Trauma in Angola is an open wound that prevents mourning as a collective catharsis. For Agualusa, there is an 
obligation to work through memories collectively so that "as pessoas se juntem, e recordem, e chorem juntas, e façam juntas o seu luto" (“A literature” 102).

Estação das chuvas deals explicitly with the open wounds of the civil war. By addressing the colonial struggle, the genesis of the MPLA and the subsequent betrayal of the movement's ideological principles, the novel attempts to reveal a truth somehow unknown (because hidden) about Angola's nation-building process.

Angolan literature has dealt with the civil war before but in a series of texts ideologically committed to the MPLA's socialist and revolutionary project. The most obvious example is the series of poems Poemas em Novembro, published by Manuel Rui every year after the independence in 1975 until 1984. During this period, there was a clear coincidence between testimony, literature and revolutionary fervor. Angolan writers were writing history through literature and did not shy away from stating it and naming their enemies. In an interview reflecting on those years, Rui admitted that he wrote "pamphlets" and that his target was "the masses." His justification was that "o nosso grande MPLA" gave him his "pátria" (Laban 722) and that MPLA soldiers "defendem este meu direito mínimo de ter papel e esferográfica para escrever" (Laban 722). As a consequence, they deserved his loyalty and his propaganda skills.

Rui helps us to understand why many writers committed their production to the service of the MPLA's ideological project. According to Rui, writers needed to fuse a testimonial tone and revolutionary enthusiasm as a "duty" to the new socialist state. But he goes further in exposing how Angolan post-independence literature had, in fact, sought to legitimize the MPLA's nation-building project: "Que foi escrito para agradar a vencedores e desagradar a vencidos é verdade" (Laban 726). Texts were imbued with the writers' ideological positions and therefore should be carefully read in that context. Read decades later, these texts are associated with the Angolan Revolution and therefore limited by their circumstances. What Rui and many other writers of his generation have not accomplished, however, is a confrontation, through their fiction or poetry, between their own 1970s socialist affiliations and the "wider picture" of postwar Angola.

Despite their sympathies, some writers began to address critically the perils of the totalizing discourse imposed by the MPLA beginning in 1975. Their writing reflected personal disillusionment with the revolutionary process as 
became patent in many novels from the 1980s onwards. Such disenchantment led to a change in attitude in Angolan literature from the "utopian texts" of the 1960s and 1970s (and those 1975-1977 texts produced at the height of the revolution), which dreamt of the possibilities of the socialist state, to a more dystopian perspective that exposed a shattered society let down by the revolution. As Ana Maria Martinho points out, dystopia is the tone of key Angolan novels published in the late 1980s and 1990s, such as Rui's Quem me dera ser onda (1989) and Pepetela's A Geração da Utopia (1992). Their disillusioned visions related "to what was missing in the former project" while "not denying it fully" (Martinho 50). In other words, "many of the intellectuals who committed themselves to formulating a revolutionary society were also its first critics. Such an attitude is in keeping with a legitimating process of their political, social, and cultural roles since independence" (Martinho 50).

Although Rui and Pepetela presented a self-criticism and a stark evaluation of Angola's socialist period, they were still committed to a change that should come from "within" the revolutionary process, not against it, nor from outside it. Cuban terminology proves useful here. During the same period (1975-1991), there was a notable Cuban presence in Angola through military, educational and ideological cooperation. Fidel Castro's iconic 1961 speech, "Palabras a los intelectuales" 'Words to intellectuals,' asserts the need for a revolutionary project to accept and embrace criticism and change from within. He enjoined those committed to the revolution (especially intellectuals) to strive to improve revolutionary praxis. At the same time, he condemned any complicity with or tolerance of dissent from those who oppose a socialist nation-building project or questioned its legitimacy. Rui and Pepetela could, in their novels, criticize the Angolan system and demonstrate their disillusionment with the way the revolution contradicted its principles, because they were able to critique it from within. In a certain way, they embodied the Cuban motto: "within the revolution, everything; against the revolution, nothing."

In contrast to Agualusa, both Rui and Pepetela belong to the generation of former MPLA guerrillas and intellectual cadres who made independence possible. They are "mais-velhos," founding figures of the nation. Agualusa was born in the 1960s, in the Huambo region, and although he is closer to some MPLA figures like Mário Pinto de Andrade and Viriato da Cruz, he belongs to a generation that did not participate actively in the anti-colonial struggle. He 
scrutinizes the controversial post-independence years in a more lucid, critical manner than authors who were writing "within" the Angolan revolution. In Angola, because UNITA was almost never heard in official spheres (such as media and culture), the single-party narrative of the MPLA, the so-called partido do povo, predominated. Although Rui and Pepetela's novels were already demonstrating their disenchantment with the status quo, Estação das chuvas marks a clear break with prior Angolan literature faithful to the MPLA, unveiling the contradictions of the independence period, revealing its unknown secrets and fears that had been buried and repressed. It establishes a contrast with the literature that proclaims the joyous years of post-1975, when many still believed in a socialist state. It proposes an alternative discourse of the nation that challenges the official narrative of the MPLA, because it deals explicitly with the fratricidal struggle, the disenchantment about the involvement of foreign powers in the war (Cuba, the USSR, USA, South Africa), the attempted coup in May 1977, and the subsequent purges within the MPLA. It demonstrates that time and distance were crucial to challenge the suspension of disbelief long characteristic of MPLA-controlled regions of the county. It drafts in a prophetic manner the contemporary, corruption-ridden nation that post-war Angola was to become.

\section{Fiction as history in Estação das chuvas}

Estação das chuvas is Agualusa's second novel. The book claims to be the "biography" of Lídia do Carmo Ferreira, an Angolan poet and historian. She studied with the MPLA's founding figures (including Pinto de Andrade and Viriato da Cruz). We learn she was arrested on Angola's independence day, released from prison some time in the 1980s and mysteriously disappeared during the 1990s. As readers, we are never really sure if Ferreira ever existed. As Mariana Carvalho highlights, she is in the acknowledgments of some of Agualusa's other books, alongside intellectuals and friends, including $O$ ano em que Zumbi tomou o Rio (2002). There are sections about her life in Um estranho em Goa (2000) and one of her poems serves as an epigraph in A conjura (1988), Agualusa's first novel in which her grandfather, Carmo Ferreira, is the protagonist. In order to present the fictional/real worlds of Ferreira, Agualusa breaks the fictional pact, creating instead an "ambiguous pact" (Cavaliere 5), bewildering the reader with the truth and verisimilitude of her existence. 
Inocência Mata argues that an obsession on the part of critics with fiction, history, truth and verisimilitude constrained the reading of Estação das chuvas, causing a "recepção do texto [que] tivesse reinvidicado a 'verdade histórica' em vez da "verdade literária"” (222).

Agualusa eventually explained the "literary truth" of his text in a conversation with Susana Moreira Marques. Marques intertwines sections from the novel with the author's statements, in order to complicate further the relation between Ferreira and Angolan history: "Ainda hoje, de vez em quando, José Eduardo Agualusa encontra alguém que pensa ter conhecido Lídia do Carmo Ferreira e ter dados sobre o seu paradeiro." In fact, according to Marques, Agualusa "nunca escreveu o final da biografia de Lídia do Carmo Ferreira, porque queria que os leitores continuassem a acreditar que ela existe, que está viva, ainda." In Marques's words, as an 84-year-old, Ferreira "provavelmente não vive em Angola: independente há quase quatro décadas, não é ainda o país pelo qual ela lutou. O seu exílio é possivelmente Portugal."

Ferreira is the leitmotiv of Estação das chuvas. She is the core of the novel. The other characters' lives and deaths revolve around her. Her story "não é apenas uma experiência individual, isolada" (Krakowska 171). She becomes "uma metonímia da nação e de todos os jovens idealistas que aspiravam pela Angola livre" (Krakowska 172). Ferreira's life functions to create what Doris Sommer has famously referred to as a "foundational fiction" about Angola (Sommer). It retells the history of the nation from the colonial period to the beginning of the anti-colonial struggle, covering the birth of the MPLA, the euphoria of independence, the civil war, the horror of 1977, and the peace process that resulted in the 1992 elections. Agualusa combines genres, voices and registers, in a metafictional strategy. The narrative alternates between historical facts enunciated by an unnamed "Bailundino" (a narrator reduced to his ethnic identity), poetry written by Ferreira (published by the Casa dos Estudantes do Império in Lisbon), writings shared with the narrator in Luanda's São Paulo prison where she was held, and interviews with her after her release in the 1990s.

Through this polyphonic mosaic of historic and fictional documents, Agualusa recreates the history of Angolan literature. That history has always been inseparable from the nation's politics. By retelling the history of the anticolonial and independence periods from a distant perspective (that of the 1990s), the author confronts the revolutionary texts of the 1970s, written by "mais- 
velhos." He challenges the version of Angolan history told by those who were writing "within the revolution."

Estação das chuvas sets out a "processo de formação da mitologia nacional" which is then "corrupted" throughout the novel (Krakowska 174). In choosing Ferreira as a main character, Agualusa "impulsiona um movimento bidireccional, por um lado, construtor e, por outro lado, desconstrutor do mito" (Krakowska 174). Ferreira challenges the myth of the past and power at the core of the MPLA. In particular, she draws attention to its foundation date. The information provided by the party in this regard changed over time. Originally 1960, it became 1956, according to Christine Messiant, as a "falsification" of the party's date of birth, "so that it appeared to predate the FNLA, [and] fed a logic that validated the MPLA as the first anti-colonial movement and dismissed its rivals as counterrevolutionary" (qtd. in Pearce 108). ${ }^{2}$

Agualusa's challenge to the legitimacy of the MPLA goes further in the novel. In the second chapter, he begins a series of allusions to a period whenpoetry was the fuel of political dreams and the anti-colonial struggle. In its dialogue between poetry and history, the "foundational fiction" of Estação das chuvas portrays the "Mensagem" generation of the 1940s with their slogan Vamos Descobrir Angola, as the heart of an Angolan poetical, political, and ultimately revolutionary project. The movement led to the emergence of an autonomous Angolan literature, rooted in African languages and cultures. It ostensibly sought to free itself from metropolitan and colonial influences. The goal of the movement was to question how assimilated Angolans knew all about Portugal's geography and culture, but nothing about their country. Vamos Descobrir Angola challenged the urban, Europeanized writers of Angola to study in detail their nation's languages, territory and customs. The movement thus became "o rito de passagem para a angolanidade: o estágio inicial de uma literatura moderna que começava a reivindicar a sua maioridade" (Santos 33).

In recalling Vamos Descobrir Angola, Agualusa invokes its principal figure, Viriato da Cruz. He would go on to be one of the founders of the MPLA. In

\footnotetext{
${ }^{2}$ See also Bittencourt who states that the lack of consensus on the date can only be understood under "a percepção da fragilidade do contexto da luta anticolonial, quer nas colônias, quer fora, nos anos 50 e $60 \ldots$ além é claro da necessidade do MPLA de aparecer no cenário international como o primeiro movimento de contestação ao colonialismo português em Angola" (23).
} 
drawing on Cruz, Agualusa questions the legitimacy of the MPLA's official history. The party discretely recognizes Cruz as its early secretary-general but always positions Agostinho Neto, who became the president of the MPLA in 1964 after a dispute with Cruz, as the founding father of the Angolan nation.

In the novel, fact and fiction are repeatedly mixed. After leaving Lisbon in the 1950s for exile in Berlin, Ferreira, who always harbored a secret passion for Viriato da Cruz, exchanges letters with the young poet in which Viriato addressed "não apenas a Lídia, mas a toda uma plateia de ouvintes - ao futuro." (Agualusa, Estação 99). Agualusa's recovery of Viriato da Cruz, a figure dropped from the Angolan literary and political canons, is significant. Viriato-the-poet was eclipsed by the ideological creation of Agostinho Neto as Angola's literary voicein-verse during the independence struggle. Cruz, the politician, dared to question Neto's leadership and, as a result, was ostracized by the MPLA. He broke with the party and ended up dying, in exile, in Beijing in 1973. Agualusa draws on a hypothetical conjecture, in essence asking: "What if Viriato was alive in the postindependence period?" It thus disturbs the reading of Angola's descent into madness after independence, by questioning the statutory discourse of "um só povo, uma só nação," one poet, one president, a single literature and a single history. That one-ness suffused the MPLA's version of Angola, both before and after independence.

"Primeiro os versos, depois as balas" (Agualusa, A educação) was Lídia, Mário, and Viriato's shared dictum. Through it, Agualusa highlights the relevance of poetry to the nationalist struggle. Yet, even by quoting António Jacinto's assertion that "é pela poesia que tudo vai começar" (Agualusa, Estação 31 ), he cannot avoid the fact that poetry was never enough to stop the bullets.

Estação das chuvas becomes a quest for an "Angolan soul" through the search for Ferreira after her disappearance. However, that search does not start chronologically in the 50s and 60s, when the poets were "discovering Angola." Instead, it begins with what Agualusa calls "o dia eterno," November 11 1975, Angola's independence day, with an epigraph from Agostinho Neto's speech. "Princípio" is the title of that chapter; "o fim" is the last chapter. Agualusa thus puts 1975 as the beginning, if not of the Angolan nation, at least an idea of the nation which tragically dies in 1992 . To Agualusa, November 11 is the beginning of the end, precisely, the end of Lídia, Mário and Viriato's verses that would no longer be sung. A song of disillusionment and persecutions would replace them, 
culminating in the May 271977 attempted coup, and the violence of its aftermath. As a character states, from then on: "É preciso cantar os fuzilamentos" (Agualusa, Estação 179).

Krakowska writes that "a viagem ao passado colonial e, simultaneamente, a infância da protagonista está inicialmente marcada por um certo encantamento nostálgico" that will be transformed into a nightmare (172). That "dia eterno," followed by the "euforia" of independence, quickly metamorphoses into a "medo" and a "fúria," leading inexorably to the "fim." However, that "fim," which establishes a clear cut with what happened in the country from the colonial period until the 1992 elections, is not the end of the country per se, but its rite of passage from infancy into adulthood. Lídia reminds us:

a infância é a estação da maldade. Claro que é também a idade da inocência. Acho que é necessária uma certa inocência para que a maldade se manifeste nas suas formas mais exuberantes. (...) Os grandes torturadores, e eu conheci alguns - enfim, nós conhecemos alguns, não foi? - os grandes torturadores são quase sempre homens que não tiveram infância e por isso a exercem mais tarde. A maldade dos homens talvez seja, no fundo, uma expressão da sua inocência. Por isso eu costumo dizer que só os inocentes são culpados. (59)

The violence, fear and torture that follow independence are, for Agualusa, an expression of the country's innocence. The nation's leaders are "guilty" of the atrocities they committed, but they are guilty because they are innocent. Like their nation, they are still in infancy, a latent state, undertaking the growing pains of becoming an adult, learning how to confront themselves with the past.

Rather than assuming independence day as the rupture between pre- and post-colonial Angola, Agualusa suggests a continuum of violence suffered by Angolans during Portuguese rule, the colonial war, and after, when the MPLA takes power. Agualusa's view resonates with Achille Mbembe's statement on the "potentate," a state that arises from anti-colonial independence, and its current status in the postcolony. According to Mbembe:

The general practice of power followed directly from the colonial political culture and has perpetuated the most despotic aspects of 
ancestral traditions, themselves reinvented for the occasion. This is one reason why the postcolonial potentate was hostile to public debate, paid little heed to the distinction between what as justified and what was arbitrary. (42)

This continuum is only interrupted by Lídia's "sonho corrompido" (Krakowska 175 ) and she reminds us constantly of the path the country is dangerously taking. Agualusa's historical research is thorough, and the nuanced contradictions throughout the novel are relevant because they provide a second layer of reading that confronts official versions of facts. This is clear when, for example, Lídia and Mário Pinto de Andrade discuss negritude, quoting Agostinho Neto: "Eu já não espero / Sou Aquele por Quem se espera." Lídia, responds the narrator, "levou muito tempo a perceber que um profeta, para ser autêntico, precisa apenas de se sentir autêntico" (82).

Estação das chuvas challenges that rhetoric of "authenticity" proclaimed by a prophetic Neto, erasing any congratulatory tone about the choices made by Angolan leaders after 1975. This can be seen in the way Agualusa addresses the various international military interventions on Angolan soil (one of the characters is a Cuban). It is also clear in his depiction of the presence of foreign mercenaries who took advantage of the Angolan conflict for a "fistful of dollars." Likewise, the gradual radicalization of the MPLA's narrative after 1975, and the sadistic details of the torture in the São Paulo prison, especially during the persecutions following the May 27, point to the author's rejection of MPLA univocality.

Although Agualusa himself was never arrested or tortured, his exhaustive descriptions seem so real that readers even thanked him for revealing the "truth":

Do Canadá recebeu uma carta de um homem que pensava que teriam estado presos juntos. No entanto, dizia, não se lembrava do nome Agualusa, nem reconhecia a cara na contracapa do livro. Será que Agualusa tinha a dada altura usado outro nome? Estava certo de que se teriam cruzado. Reconhecia várias daquelas situações. Lembrava-se até daquele tenente boére e dos seus cursos de astronomia. (Marques)

Agualusa dares to reveal the possibility of remembering what many Angolans have been told to forget. It is as if those "buried memories" were not allowed to 
come to the surface, therefore drafting a failed revolutionary project in the apparent contradiction, still obvious in today's Angola, of victims and torturers as cohabitants who end up eating "funjadas" at each other's homes (Agualusa, Estação 252). Winners and losers, those who spoke, those who remained silent, and those who are still looking for bodies that have never been retrieved, are mixed together in an uncompromising narrative of revelation. Regardless of the confusion between truth and verisimilitude, Estação das chuvas confronts the "buried memories" that Richard Werbner called "unfinished narratives." "Subjected to buried memory, people do not so much forget as recognize-and often even more forcefully - that they have not been allowed to remember" (9).

Agualusa remembers and allows his characters to voice the trauma that has remained hidden for so long. The nation's schizophrenia is embodied in the "conviviality" of the Prisão de São Paulo - the same prison where the PIDE used to detain anti-colonial fighters. Also, it was the same prison where the February 41961 attack took place, considered the beginning of the colonial war against Portugal. The continuum between colony and postcolony, violence and postindependence fear is blatant in the use of this space, cohabited by several characters, ${ }^{3}$ which becomes a microcosm of Angola. The space attests to Mbembe's assertion that the "postcolonial mode of domination is a regime that involves not just control but conviviality; even connivance." The reader must "watch for the myriad ways ordinary people guide, deceive, and toy with power instead of confronting it directly" (Mbembe 128). The "conviviality" of these characters in the prison moves beyond an idea of resistance or opposition: "The logic of conviviality [is] the dynamics of domesticity and familiarity, inscribing the dominance and the dominated within the same episteme" (Mbembe 110).

Following a logic of conviviality that, to a certain extent, challenges the logic of defiance and opposition, Agualusa allows us to doubt who is real and who is not. He plays with a margin of uncertainty since there are characters we recognize

\footnotetext{
${ }^{3}$ In the prison, the following prisoners are "gathered": Lídia do Carmo Ferreira; the narrator of the novel, Bailundino; Aristides Lobo d'África, a former official of the Portuguese army, famous for his brutality during the colonial war; Santiago, a prison warden who after 1977 becomes a prisoner himself; foreign mercenaries: a South African and a Cuban-American; and Francisco Borja Neves and Joãoquinzinho, like some of the others, accused of belonging to OCA (Organização Comunista de Angola) and conspiring against the state, i.e., the MPLA.
} 
from history and others we cannot quite place. Blending fiction and history is done on purpose. One must assume that there are no innocent or guilty, good or evil figures. Everyone's hands are dirty because everyone is already to some extent "dead": "Caminho por estas ruas e o que vejo são cadáveres. Estão todos mortos. Há um que passa por mim. Digo-lhe: estás morto. E ele ri-se" (Agualusa, Estação 255).

At the end of the novel, Agualusa presents once more the contradiction of days of hope with the coming 1992 elections juxtaposed with the visible destruction of the city which, when the election results are released, descended again into a vortex of madness and chaos that only ended in 2002. This clear "fim," marking the end of Angola's innocence, could also be read as the definite ending of Angola's revolutionary period. The end of Angola's innocence entailed the end of its socialist dream, encapsulated in mottos like "um só povo, uma só nação," "a vitória é certa" and "o MPLA é o povo, o povo é o MPLA." Perhaps in 1975, at the height of independence euphoria, it was logical to assume the MPLA's version of history, blending the nation and the party. The triumphal coincidence between "nação" (Angola), "partido" (MPLA) e "estado" (government/MPLA), to which one should add "história" and "literatura," is demolished in Estação das chuvas, chapter by chapter. Agualusa exposes the anachronistic nature of the MPLA mottos (still used today) demonstrating with his polyphonic novel (and giving voice to those who have been silent and silenced) how "este país morreu" (Agualusa, Estação 265).

\section{Conclusion}

As an embryonic portrayal of a country morally destroyed by a fratricidal war and as an alternative reading of Angolan history (confusing purported fiction and fact), Estação das chuvas disputes the idea of the Angolan nation as conceived by the MPLA, the sole victor of its various wars. The novel defies the notion of an ultimate truth when narrating, through literature, the history of the civil war and the independence period, deconstructing the revolutionary process. It also clearly exposes the "postcolonial potentate" Angola has become, "wove[n] between the production of violence and the arrangements for allocating privileges and means of livelihood" (Mbembe 43). It seems to prove the assertion that the stability thus acquired, and apparently reinforced through the institutions 
designed to dragoon and regiment society — such as single party, single trade union, party youth and women's associations, "praise associations" responsible for orchestrating the personality cult - was illusory (Mbembe 48-49).

In such circumstances, memory becomes crucial. Estação employs it as a solution to many contentious issues in Angola. As a society that has not been allowed to remember, Angola, and inevitably its literature, is still in the thrall of "buried memories." In giving voice to those who have been silenced by history or the canon, Agualusa contributes to a version of history which can be contradictory, fragmentary or even fictional - as the novel displays breaking up chapters, flashbacks, polyphony or personal quests. Narrating history through literature is, thus, key to an alternative discourse that challenges the uniformization of memory by victors.

Angolan literature seems to have been telling the story of the victors over and over, but not really challenging "uma historiografia de sentido único, questionando a organicidade dos heróis e dos mitos nacionais" (Menezes 318). The single nation-party-state rhetoric promoted the past "para criar a memória política que favoreça e reforce a "sua' ideia de nação" (Menezes 319). ${ }^{4}$ Agualusa's novel, opening with a clear "princípio" and finishing with "este país morreu," is a hybrid of genres, letters, poetry, journalism and memoir. It fragments Angola's history in an attempt to decolonize it, especially from a narrative of the powerful. Estação das chuvas, written at the height of the second phase of the civil war, demonstrates that rather than one voice, one party and one nation, history is a narrative full of breaks, small chapters, different voices and stories intertwined that show us the "ideia de nação" is still very much in pieces.

\section{Works Cited}

Agualusa, José Eduardo. A conjura. Lisbon: Caminho, 1988. Print.

—. A educação sentimental dos pássaros. Lisbon: Dom Quixote, 2011. Print.

—. "A literatura angolana e a representação da guerra pela independência, da guerra civil e da violência urbana.” Revista Diversitas 1.1 (2013): 101-05. Web. 9 Dec. 2015.

\footnotetext{
${ }^{4}$ Here Menezes is referring to Mozambique but her assertion is equally applicable to Angola.
} 
-. Estação das chuvas. 1996. Lisbon: Dom Quixote, 2007. Print.

-. O ano em que Zumbi tomou o Rio. Lisbon: Dom Quixote, 2002. Print.

-. Um estranho em Goa. Lisbon: Cotovia, 2000. Print.

- ."Viriato da Cruz e o poder da poesia." Buala. 15 Mar. 2011. Web. 9 Dec. 2015.

Bittencourt, Marcelo. “A criação do MPLA”. Estudos Afro-Asiáticos 32 (1997): 1-35. Print.

Castro, Fidel. "Palabras a los intelectuales.” 1961. Latin American Network Information Center. Web. 14 Feb. 2012.

Caruth, Cathy. Unclaimed Experience: Trauma, Narrative and History. Baltimore, MD: Johns Hopkins UP, 2010. Print.

Carvalho, Mariana. “'As personagens começam a existir no momento em que nos aparecem em sonhos'-construção e representação de personagens agualusianos." Anais do V Seminário dos Alunos dos Programas de PósGraduação do Instituto de Letras da Universidade Federal Fluminense. Rio de Janeiro: U Federal Fluminense, 2014. 48-56. Web. 9 Dec. 2015.

Cavaliere, Mauro. "Autoficção e história: a hibridez do pacto de leitura em Estação das chuvas, de José Eduardo Agualusa." 19th Congrès des Romanistes Scandinaves (2014): 1-10. Web. 9 Dec 2015.

Chabal, Patrick. Postcolonial Literature of Lusophone Africa. London: Hurst, 1996.

Erll, Astrid, and Ann Rigney. "Literature and the Production of Cultural Memory." European Journal of English Studies 10.2 (2006): 111-15. Print.

Jamba, Sousa. Patriots. New York: Viking, 1990. Print.

Krakowska, Kamila. "As viagens das nações pós-coloniais em Estação das chuvas e Terra Sonâmbula." Nação e Narrativa Pós-colonial I: Angola e Moçambique. Ed. Ana Mafalta Leite, et al. Lisbon: Colibri, 2012. 169-83. Print.

Laban, Michel. Angola: Encontro com escritores. 2 vols. Porto: Almeida, 1991. Print.

Martinho, Ana Maria. "Utopian Eyes and Dystopian Writings in Angolan Literature." Research in African Literatures 38.1 (2007): 46-53. Print.

Marques, Susana Moreira. "À procura de uma poeta e da esperança angolana." Público 1 Sept. 2012. Web. 9 Dec. 2015. 
Mata, Inocência. Silêncios e falas de uma voz inquieta. Lisbon: Mar Além, 2001. Print.

Mbembe, Achille. On the Postcolony. Berkeley: U of California P, 2001. Print.

Menezes, Maria Paula. "Nação e narrativas pós-coloniais: interrogações acerca dos processos identitários em Moçambique." Nação e Narrativa Pós-colonial I: Angola e Moçambique. Ed. Ana Mafalta Leite, et al. Lisbon: Colibri, 2012. 311-22. Print.

Pearce, Justin. "Contesting the Past in Angolan Politics." Journal of Southern African Studies 41.1 (2015): 103-19. Print.

Pepetela. A Geração da Utopia. Lisbon: Dom Quixote, 1992. Print.

Rui, Manuel. "Cinco Dias Depois da Independência”. Sim, Camarada! Lisbon: Edições 70, 1977: 95-191. Print.

-. Cinco Vezes Onze: Poemas em Novembro. Lisbon: Edicões 70, 1984. Print.

- . Quem me dera ser onda. Lisbon: Cotovia, 1991. Print.

Santos, Donizeth Aparecido. "Da ruptura à consolidação: um esboço do percurso literário angolano de 1948 a 1975." Publicatio 15 (2007): 31-42. Print.

Sommer, Doris. Foundational Fictions: The National Romances of Latin America. Berkeley: U of California P, 1993. Print.

Werbner, Richard, ed. Memory and the Postcolony: African Anthropology and the Critique of Power. London: Zed, 1998. Print. 